\title{
Tellegens dieren in het Poolse bos. De dubbele bodem en het visuele aspect bij Toon Tellegen in Poolse vertaling
}

\begin{abstract}
This paper presents the results of a comparative analysis of two works by Dutch (children's) author Toon Tellegen and their translations into Polish. The article focuses on the cultural context adaptation of the dual address for children and adults in his works on the one hand, the textual and visual cohesion on the other. The analysis will show that, while the translated text favors a foreignization approach, treating the child as a full-fledged reader and allowing the adult to find merit in these stories, too, the visual adaptations lean towards domesticating it for the Polish cultural context.
\end{abstract}

Keywords: children's literature, translation, cultural context adaptation, domestication, foreignization, illustration, dual address.

\section{Inleiding}

Want het zou niet lang duren voor ze naast elkaar zouden zitten en elkaar duizend en een dingen zouden vertellen die je toch nooit kon schrijven.

uit: Toon Tellegen, Bijna iedereen kon omvallen (89)

Jeugdliteratuur in vertaling is een bijzonder fenomeen. Het betreft immers twee onderdelen van de belletrie die zich doorgaans in de marge bevinden en niet steeds een analyse waardig geacht worden. Wanneer het bovendien gaat over Nederlandstalige jeugdliteratuur in Poolse vertaling - twee eerder kleine taalgebieden, lijkt die status alleen nog maar meer perifeer te worden. Toch is het tegenovergestelde waar, want wanneer we bestuderen hoe een literair werk voor de jonge lezer zich gedraagt wanneer het terecht komt in een nieuwe literaire en 
maatschappelijke context, is daaruit veel af te leiden over zowel het bronsysteem waaruit de tekst afkomstig is, als over het doelsysteem waarnaar hij omgezet wordt. Deze theorie van de cultural context adaptation vormt de basis voor onderhavig artikel en wordt toegelicht in punt 2, waarna aan de hand hiervan twee werken van Toon Tellegen, De verjaardag van alle anderen en Bijna iedereen kon omvallen, en hun Poolse vertaling, geanalyseerd worden.

Bron- en doeltekst worden met elkaar vergeleken op twee kenmerken die vaak aan Tellegens kinderboeken worden toegeschreven (punt 3). Enerzijds is er de double address in zijn verhalen: zijn dierenverhalen lijken worden uitgegeven voor kinderen, maar de filosofische ondertoon spreekt ook oudere lezers aan. "Van de scheidslijn tussen jeugdboeken en boeken voor volwassenen heeft Tellegen zich nooit iets aangetrokken", zo schrijft Jos Staal (6). Ook wanneer Tellegen in recensies wordt ingeleid, wordt vaak vermeld dat zowel volwassenen als kinderen zijn werk kunnen smaken: zo schrijft ook de literaire blog Tzum dat de verhalen "literatuur zonder leeftijd" (Klaver 2021) zijn voor zowel kleuters, pubers, als volwassenen. Bovendien zal blijken dat de double address niet alleen slaat op de lezer, maar ook op de (volwassen) voorlezer, en dat de volwassene ook in het schrijf- en publicatieproces nu eenmaal meer te zeggen heeft dan het kind. Het tweede kenmerkende element van Tellegens werk voor kinderen is de samenhang tussen het tekstuele en het visuele aspect, of het gebrek daaraan; de prenten worden in het originele Nederlands sober tussen de tekst ingevoegd, terwijl de dierenverhalen in Poolse vertaling een ander, kleurrijker uiterlijk krijgen. De vraag is dus hoe de Poolse vertalingen van deze twee werken van Tellegen omgaan met de double address enerzijds, en de samenhang tussen tekst en beeld anderzijds.

\section{Cultural context adaptation, de dubbele lezer en het visuele aspect}

\subsection{Aanpassing aan de culturele context}

Een eerste gegeven dat in academische literatuur reeds uitgebreid behandeld is, is dat van de cultural context adaptation. Deze overkoepelende term probeert de veelheid aan factoren te beschrijven op basis waarvan beslist moet worden in welke mate een origineel werk kan worden aangepast om naar behoren te functioneren in de doelcultuur (Lathey, "Introduction" 7; naar Klingberg 1986). Hoe dicht de vertaling in inhoud en stijl moet aanleunen bij het origineel, is een bekend punt van discussie. Volgens sommige onderzoekers en vertalers kan een vertaler meer vrijheid nemen om te vermijden dat het kind geconfronteerd wordt met elementen die het toch niet herkent of begrijpt (Szymańska 156). Dit maakt van de jeugdliteratuur in vertaling overigens een bijzonder dankbaar onder- 
zoeksobject, omdat zij meer dan andere literaire subsystemen verschillen tussen culturen aan het licht kan brengen (López 42). Shavit (26) haalt twee situaties aan waarbinnen het geoorloofd is aanpassingen door te voeren. Ten eerste kan de opvoeding van het kind aangewend worden als motivatie: de vertaler kan het verhaal zodanig bijwerken dat het overeenstemt met de op dat moment en in die cultuur geldende conventies van wat goed is voor het kind. Ten tweede kan de vertaler adaptaties maken op basis van de bekwaamheid van het kind tot lezen en begrijpen (cf. infra).

Cultural context adaptation stelt dat jonge lezers doorgaans meer moeite hebben met het verwerken van vreemde elementen, zoals buitenlandse eigennamen, toponiemen of andere culturele elementen, niet eigen aan hun vertrouwde cultuur (Pounds 278). Die vreemde elementen kunnen evenwel niet-tekstuele onderdelen zijn: ook het visuele aspect, zoals illustraties of vormgeving, speelt mee en zelfs de verborgen subtekst ${ }^{1}$ kan vertaald worden. De vraag rijst dus voor welke van die elementen een inheems equivalent gezocht moet worden en welke onvertaald kunnen blijven. Voor beide benaderingen valt iets te zeggen, zo schrijft Lathey ("Introduction" 7-8): bij het vertalen van zulke cultuurspecifieke termen wordt een beter begrip van de tekst door het kind gegarandeerd. Het kind identificeert zich met de culturele context van het verhaal. Humor, ironie of een eventuele moraal zullen de jonge lezer makkelijker bereiken. Maar, zo nuanceert Lathey ("Introduction" 7-8) verder, kinderen tonen zich doorgaans meer dan volwassenen ontvankelijk voor het onbekende. De aanwezigheid ervan kan hen helpen geboeid te raken door andere culturen en aldus al op vroege leeftijd hun wereldbeeld verdiepen. Deze twee methoden - vertalen met een cultuureigen equivalent versus onbekende realia onvertaald laten - worden in de vakliteratuur respectievelijk domestication of naturalization en foreignization of estrangement genoemd (Pounds 278).

Daarnaast is er ook nog de aurea mediocritas, in dit geval cultural mediation, of (inter)culturele mediatie (Lathey, "The Translator Revealed" 8-10). De vertaler gaat als bemiddelaar op zoek naar een aurea mediocritas: door het toevoegen van paratekstuele elementen ${ }^{2}$ zoals een inleiding of voetnoten tracht hij de lezer te helpen bij de receptie. De manier waarop dit gebeurt, is vaak tekenend voor de culturele representatie van de broncultuur in de doelcultuur - soms zelfs letterlijk, wanneer deze representatie tot uiting komt via illustraties in het jeugdboek. Vaak

1 Volgens het Algemeen Letterkundig Lexicon is de subtekst de "diepere, impliciete betekenis of bedoeling die zich verschuilt achter een mededeling of een tekst, maar die door de spreekwoordelijke goede verstaander achterhaald kan worden in de interpretatie ervan". Zie http://www.dbnl.org/ tekst/dela012alge01_01/. Geraadpleegd op 27 april 2017.

2 Volgens het Algemeen Letterkundig Lexicon is de paratekst "een term ter aanduiding van al wat zich rond een tekst bevindt, d.w.z. alle tekstuele gegevens die de "eigenlijke" tekst aan de lezer als tekst presenteren en die voor hem als drempels, richtingwijzers, valstrikken e.d. kunnen fungeren". Zie http://www.dbnl.org/tekst/dela012alge01_01/. Geraadpleegd op 7 april 2017. 
wordt immers bij deze toevoegingen de nadruk gelegd op het "permanente en inherente anders-zijn" van de broncultuur, wat vervreemding in de hand werkt, zeker bij een jonge lezer (Lathey, "The Translator Revealed" 8-10). Op deze manier kan daarenboven niet enkel over de doelcultuur op zichzelf informatie verkregen worden, maar ook over het beeld van het kind dat deze cultuur uitdraagt. Hoe kijkt een maatschappij naar het kind en de kindertijd? Is het kind voor de vertaler "naïef en onschuldig of verstandig en ervaren" (Oittinen, "No Innocent Act" 41)? Dit 'kindbeeld' is allicht vaak een individuele aangelegenheid, maar tot op zekere hoogte ook iets dat "gecollectiviseerd is in de maatschappij" (Oittinen, "No Innocent Act" 42).

\subsection{Relatie tussen volwassene en kind}

\subsubsection{Het geheim van de dubbele lezer. Dual address}

Jeugdliteratuur vertalen gaat niet louter om het omzetten van een tekst van de ene taal naar de andere, het houdt ook het omzetten van een tekst van het doelpubliek naar een ander in: van de volwassen lezer naar het kind (Shavit 25-26). Een verhaal voor kinderen heeft niet enkel hen als lezer; ook de volwassene leest mee én voor. Deze relatie tussen beide heet de dual of ook wel double address: het kind is misschien wel de belangrijkste geadresseerde, maar ook de volwassen lezer kan zijn gading vinden in de verhaallijn of als (voor)lezer en verteller (Dymel-Trzebiatowska 196-197, naar Wall 1991).

Literatuur voor jonge kinderen heeft vaker dan die voor oudere lezers een eenvoudige structuur en simpele, alledaagse taal, zowel grammaticaal als lexicaal: er is meer dialoog en concrete actie en er zijn minder descriptieve of introspectieve scènes. Kortom, "het concrete gaat boven het abstracte, onbepaalde of dubbelzinnige, beweging en actie gaan boven traagheid en reflectie, zekerheid boven waarschijnlijkheid" (Rudvin \& Orlati 162-163). Toch is ook een verhaal voor de jeugd op zijn eigen manier abstract. Ghesquière (2009) geeft enkele voorbeelden van deze abstractheid: de aangesneden thema's zijn niet steeds kinderlijk; niet zelden wordt een moraal over vriendschap, familie, liefde of andere algemene onderwerpen "des levens" op een aangepaste manier tot bij het kind gebracht; fantasie en magie worden niet geschuwd; de taal is humoristisch, speels en vrij.

Lathey ("Introduction" 5) wijst op de belangrijke taak die de vertaler heeft: hij moet de "asymetrie in de relatie tussen volwassene en kind", en de subtielere subteksten, correct opmerken en omzetten, wat de nodige ervaring en voeling met beide werelden vereist. Die asymetrie blijkt niet alleen uit de vertaling, die voornamelijk door volwassen handen gaat. Ook andere fases van het publicatieproces worden vooral bepaald door de volwassene. Kinderen zijn dus afhankelijk van de 
voorkeuren van volwassenen, niet alleen bij de productie, maar ook daarna: hoe en wat er gelezen wordt is vaak in grote mate een keuze van de volwassene. Ook dit is een belangrijk aspect van de dual address (Oittinen, "No Innocent Act" 36; Ghesquière, "Why Does Children's Literature Need Translations?" 17).

\subsubsection{De kunst van het voorlezen. Read-aloud ability}

Veel meer dan andere tekstsoorten worden boeken voor jonge kinderen geschreven om luidop gelezen te worden - ook dat is deel van de dual address. Ritme, zinsstructuur, interpunctie, stijl en opbouw van de tekst zijn daarbij van groot belang. De voorlezer moet voldoende potentieel in de tekst vinden om door middel van intonatie, toon, tempo, rustpunten en nadruk de toehoorder te blijven boeien (Oittinen, "No Innocent Act" 39). In welke mate een tekst voldoet aan dit geheel van kenmerken kan de read-aloud ability van een tekst genoemd worden (Puurtinen 56). Bovendien kunnen zowel kind als volwassene optreden als voorlezer en luisteraar, wat de uitdaging voor de vertaler alleen nog maar groter maakt. Van Coillie (350-351) maakt een onderscheid tussen twee soorten van aanpassingen die kunnen gebeuren in relatie tot de read-aloud ability van de tekst: aanpassingen op het structurele en het stilistische niveau. Onder het structurele niveau worden uiteraard tekststructuur en indeling begrepen, maar ook het effect van vormgeving en illustraties. Fonologische, lexicale, syntactische en pragmatische veranderingen behoren tot het stilistische niveau.

\subsection{Het visuele aspect vertalen}

De hoofdtekst van een jeugd- of kinderboek wordt vaak vergezeld van illustraties. Hierin schuilt opnieuw een uitdaging voor de vertaler: ook dit extra medium heeft immers een impact op de vertaling. Het is belangrijk dat de vertaler er zich van bewust is hoe het tekstuele en visuele element samengaan; de interactie tussen beide is namelijk ingewikkelder dan louter ondersteuning van de tekst door het beeld. Die samenhang kan zich uiten op verschillende manieren, die grofweg kunnen ingedeeld worden in vier categorieën: "descriptief, suggestief (het opwekken van een bepaalde sfeer of stemming), decoratief en expressief" (Oittinen, "On translating picture books" 114, naar Shulevitz 1985). De aard van de illustratie kan een belangrijke rol spelen bij de domestication of foreignization van de vertaling. Dit gebeurt zowel in de eerder gebruikte betekenis van die termen, i.e. het meer of minder tegemoetkomen aan de doelcultuur, als binnen de tekst zelf: de illustraties vormen een goed geolied geheel, of vervreemden de lezer net van de inhoud van de tekst. In vertalingen van geïllustreerde kinderboeken (prentenboeken, strips of graphic novels buiten beschouwing gelaten) zien we dan ook vaak dat opzettelijke leemtes toch worden opgevuld door de tekst, wat het geheel 
zonder twijfel minder rijk maakt (O'Sullivan 113-114). Schwarcz (14-18) heeft het wat betreft het samenspel tussen het tekstuele en visuele aspect over congruency en deviation. Een illustratie die congrueert met de tekst insinueert in beeld meer dan wat met woorden verteld wordt. Bij een afwijkende illustratie gaat het eerder om een illustrator die inspiratie zoekt bij het tekstuele aspect, maar zich hier niet op vastpint. Doorgaans laat de tweede variant de lezer meer vrijheid om zelf op zoek te gaan naar wat hij waardevol vindt in de tekst.

Wanneer een jeugdboek vertaald wordt, wordt aan illustraties en vormgeving vaak niet geraakt. Soms vinden bepaalde aanpassingen toch plaats, bijvoorbeeld wanneer tekst en beeld zo nauw met elkaar verweven zijn dat de receptie verstoord zal worden wanneer bepaalde elementen onvertaald blijven. Alteraties in het visuele aspect van het jeugdboek kunnen gebeuren op veel verschillende niveaus. Zo kunnen visuele symbolen, zoals gebaren of de symboliek van kleuren, cultuurgebonden zijn. Het kan echter ook gaan om subtielere verschillen die te maken hebben met vorm, dimensie, ruimtelijkheid, belichting, beweging, perspectief, tint, helderheid en zelfs geluid. Ook typologie, compositie en algemene lay-out kunnen mee in rekening gebracht worden (Oittinen, "On translating picture books" 112-114).

\section{Tellegens dieren verhuizen naar het Poolse bos}

\subsection{Omschrijving van de werken}

Om dit alles aan de praktijk te kunnen toetsen, liggen twee werken van de Nederlandse auteur Toon Tellegen ter analyse voor: Bijna iedereen kon omvallen (1993), met illustraties van Anne van Buul, en De verjaardag van alle anderen (1998), geillustreerd door Geerten Ten Bosch. Beide werken bevatten een verzameling van korte dierenverhalen en werden naar het Pools vertaald door Jadwiga Jędryas en uitgegeven bij Wydawnictwo Dwie Siostry in Warschau. Respectievelijk verschenen zij onder de titels Nie każdy umiat się przewrócić (2013) en Urodziny prawie wszystkich (2014). Opvallend is dat de originele afbeeldingen bij beide publicaties plaats hebben gemaakt voor een geheel nieuwe vormgeving, met illustraties door Ewa Stiasny.

De werken van Tellegen in vertaling zijn om verschillende redenen interessant voor een vertaalanalyse. Zoals eerder besproken komt de dual address in zijn dierenverhalen duidelijk naar voren. Ook aan de hand van de wel zeer drastische aanpassingen aan de oorspronkelijke illustraties kunnen conclusies getrokken worden over welke manier van cultural context adaptation het Poolse doelsysteem hanteert. 


\subsection{Van een Nederlandse naar een Poolse culturele context}

In dit onderdeel wordt besproken hoe de vertaling van Bijna iedereen kon omvallen en De verjaardag van alle anderen door middel van weglatingen, toevoegingen, aanpassingen, of het gebrek hieraan, gepoogd heeft tegemoet te komen aan de Poolse lezer.

\subsubsection{Toevoeging van paratekstuele elementen}

De paratekstuele elementen in de originele, Nederlandstalige uitgaven zijn eerder beperkt. Bij De verjaardag van alle anderen ontbreekt een inleiding of flaptekst. Bijna iedereen kon omvallen beperkt zich tot een flaptekst met een uittreksel uit het boek, een overzicht van de toegekende prijzen en volgende zin: "Voor iedereen vanaf een jaar of tien en (veel) ouder". Het lijkt wel alsof Tellegen in het Nederlandse taalgebied geen introductie meer nodig heeft.

Aan de Poolse uitgaven daarentegen wordt, naast een tekstfragment, een uitgebreide voorstelling van de auteur en zijn genre toegevoegd. Het is logisch dat Tellegen in vertaling meer inleiding vereist. Toch valt het op dat de flapteksten met name inspelen op elementen die zijn werk in het Poolse doelsysteem legitimiteit kunnen verlenen: de bekendheid ervan in het eigen taalgebied, en de uniciteit van het genre (Czarnecka 13). Verder wordt net als op de originele flaptekst vermeld dat de verhalen geschikt zijn voor zowel volwassenen als kinderen, een onmiskenbaar bestanddeel van Tellegens werk dat werd opgemerkt en uitgespeeld. ${ }^{3}$

\subsubsection{Cultuurspecifieke elementen in de tekst}

Doordat het de verhalen van Tellegen ontbreekt aan een specifieke setting, is het aantal cultuurspecifieke elementen in de tekst klein. Zijn verhalen zijn daardoor uniek en toch universeel. Wel zijn er termen te vinden die op het eerste gezicht minder vaak voorkomen in een verhaal voor kinderen. Het gaat voornamelijk om soortnamen van planten en dieren. Enkele voorbeelden: "moerbeiboom" drzewo morwowe; "relmuis" - popielica; "ransuil" - sowa uszata; "de coelacant,

${ }^{3}$ Uit De verjaardag van alle anderen: "Absurdalnymi historiami o zwierzętach wykreował oryginalny literacki świat, który urzeka zarówno dzieci, jak i dorosłych". ("Hij creëerde aan de hand van absurde dierenverhalen een originele literaire wereld die zowel kinderen als volwassenen betovert" [vert. KB]). Uit Bijna iedereen kon omvallen: "Dowcipne, melancholijne, filozoficzne, poetyckie, wzruszające - bawią i zachwycają czytelników w każdym wieku. (...) Tellegen wykreował zupełnie nowy gatunek literacki. Stał się niezwykle popularny zarówno wśród dzieci, jak i wśród dorosłych”. („Humoristisch, melancholisch, filosofisch, poëtisch, aangrijpend: lezers van elke leeftijd zullen hiermee lachen en van genieten. (...) Hij creëerde een volledig nieuw literair genre en werd ongekend populair bij zowel kinderen als volwassenen" [vert. KB]). 
de ocelot, de scarabee en de opossum" - latimeria, ara, skarabeusz i ocelot. Tellegens keuze voor deze minder gekende soorten wordt zonder meer overgenomen met een equivalente Poolse soortnaam. Jędryas ziet er geen graten in de Poolse lezer te verrassen met originele frasen en neologismen als "je verjaardag in de zee gooien" - wyrzucić urodziny do morza; "tegen een grasspriet trappen" - kopnać źdźbło trawy; "wegglibberen" - odpetzać; "Nog een prettige oertijd dan!" - W takim razie miłych praczasów!; "zo schriftelijk mogelijk leven" - żyć tak pisemnie, jak tylko się da; "dankmijwel" - dziękuję sobie bardzo. Verder kan de kever probleemloos een liedje blijven tsjirpen en hoeft hij niet te zingen, de zandvlieg wrijft zijn voelsprieten over elkaar en niet zijn handen en de vleugels van de mug kunnen ook in het Pools rood worden van opwinding.

De vertaalster acht het niet nodig haar jonge lezer af te schermen van onbegrijpelijke taal. Een drang om de kinderlijke onschuld te beschermen hebben de verhalen van Tellegen sowieso al niet in zich. Ze raken aan thema's die in iedere levensfase relevant zijn, en eerder dan te proberen antwoorden te bieden die conform maatschappelijke en sociale conventies zijn, roepen zij vragen op en nodigen de lezer uit tot een gesprek. Dat heeft Tellegen zelf overigens meermaals bevestigd, bijvoorbeeld in Staal (2010, naar Boonstra 2009): "Ik heb ze gewoon geschreven en nooit speciaal voor kinderen. Van wat kinderen leuk vinden, heb ik geen verstand".

\subsection{Tellegens dieren in een Pools jasje}

Eén van de meest opvallende verschillen tussen de originele uitgave en de Poolse vertaling is de nieuwe vormgeving. De Poolse versies van De verjaardag van alle anderen en Bijna iedereen kon omvallen zijn uitgesproken gericht op kleinere kinderen (Kalla 63). Dat is al duidelijk bij een eerste blik op de omslag: de Poolse uitgaven maken gebruik van felle kleuren, een tekening die de volledige kaft in beslag neemt en een titel die wel door een kind gekrabbeld lijkt. De Nederlandstalige uitgaven zijn veel soberder. Een belangrijke kanttekening is wel dat, net zoals bij de toevoeging van paratekstuele elementen, het herwerken van de illustraties vaak ook een persoonlijke keuze van de uitgever is, en dat uit wat volgt natuurlijk niets met zekerheid gesteld kan worden over de Poolse context in zijn geheel.

\subsubsection{Abstract en bescheiden - magisch en gedetailleerd}

In beide Nederlandstalige uitgaven zijn de prenten zwart-wit. Anne van Buul tekent in een gestileerde, abstracte stijl, met krachtige, zwarte lijnen. Ze volgt de stijl van "oermoeder" Mance Post, die voor menig fan van Toon Tellegen onlosmakelijk verbonden is met zijn dierenverhalen door haar kenmerkende stugge en onrealistische linoleumsneden (Vrooland-Löb 63). De illustraties van Geerten Ten 
Bosch zijn werkelijkheidsgetrouwer, maar wijken door hun beweeglijke lijnenwerk en rijkdom aan donkere schaduwen ook af van wat men vaak verstaat onder een klassieke kindertekening. Tekst en beeld zijn in de originele uitgaven niet erg nauw verbonden: de bladspiegel is op iedere pagina identiek en illustraties worden gewoon tussen of onder de tekst ingevoegd. De tekst zou ook op zich prima te lezen zijn, zonder dat de illustraties informatie aanbieden die noodzakelijk is om het verhaal te begrijpen. Ook de vormgeving van beide boeken is bijzonder eenvoudig. Er werd niet gewerkt met fantasielettertypes - hoogstens cursivering - of speciale composities. Bovendien worden Tellegens boeken geïllustreerd door veel verschillende tekenaars of zelfs van nieuwe illustraties voorzien bij een heruitgave, zoals bij enkele verhalen uit Bijna iedereen kon omvallen, die eerder al in NRC Handelsblad verschenen, vergezeld van prenten van Annemarie van Haeringen. Men maakt het zo de jonge lezer niet erg gemakkelijk: er is een gebrek aan consistentie door deze "heterogene beeldvorming" (Vrooland-Löb 66, 68).

De illustraties in de Poolse uitgave zijn veel prominenter aanwezig. Eerst en vooral zijn er prenten in kleur die bovendien nauw aansluiten bij de inhoud van het verhaal: een oranjerode zonsondergang vult het blad wanneer de tor in de steppe dwaalt, een felgele achtergrond wanneer de olifant en de eekhoorn zonnen aan de rivier of een gitzwarte pagina wanneer de inktvis een zwarte verjaardagstaart bakt op de bodem van de oceaan. Soms nemen de prenten twee volledige bladzijden in beslag en vaak wordt tekst bovenop of rondom de illustraties geplaatst. Elementen die in het verhaal door de dieren met de hand geschreven zijn, zoals brieven, uitnodigingen of lijstjes, worden door illustratrice Ewa Stiasny ook echt zo weergegeven: met slordige, kinderlijke drukletters. Haar prenten doen in het algemeen wat feeërieker of magischer aan dan de interpretaties van Anne van Buul of Geerten Ten Bosch, enerzijds door het kleurgebruik, anderzijds ook door meer details en de variatie in de bladspiegel. De Poolse tekeningen staan veel dichter bij de tekst dan de originele lijntekeningen: niet alleen omdat ze letterlijk tussen en met de tekst verweven zijn, maar ook omdat ze vaker één scène of zelfs één zin afbeelden. Dat is niet zo bij de originele prenten, die algemeen gelden voor het hele verhaal waarbij ze horen, bijvoorbeeld omdat ze slechts een personage laten zien. Terugverwijzend naar O’Sullivan (113-114) en Schwarcz (1418) laten de nieuwe illustraties nog maar weinig aan de verbeelding over. Het doet afbreuk aan net datgene wat de verhalen van Tellegen met name onder volwassenen zo succesvol maakte: hun filosofische aard en het feit dat eenieder tussen de lijnen een boodschap kan vinden die aanspreekt.

\subsubsection{De aard van het beestje: het uiterlijk van Tellegens dieren}

Een belangrijk verschil betreft het uiterlijk van de dieren. In de originele tekst past de olifant probleemloos door de deur van de mier en kunnen zij zonder fysieke 
ongemakken met elkaar dansen. Hun geslacht is niet af te leiden uit tekst noch illustraties en is dus ook niet van belang. Tellegens dieren "vertonen geen bekende dierentrekjes en vallen buiten de wetten van het alledaagse" (Boshouwers 66): hoe zij eruitzien is niet belangrijk, wel hun dromen, gedachten en belevenissen.

De Poolse equivalenten daarentegen vertonen veel explicietere uiterlijke kenmerken. Het opvallendst is de mier, die uitgedost is in roze tenue en op hoge hakjes loopt. Wanneer de eekhoorn en de olifant samen aan tafel zitten, raakt de ene met zijn - of haar - poten de grond niet, terwijl de stoel kreunt onder het gewicht van de andere. Wanneer de tor door de hete steppe loopt, draagt hij een stoere, geruite hoofddoek. De kreeft gaat gekleed in een gestreept maatpak. Niet enkel door hun kleding, maar ook grammaticaal wordt het geslacht van de Poolse dieren onthuld: "Het Pools kent [in tegenstelling tot het Nederlandse tweegenerasysteem] een driegenerasysteem. Het is niet zo dat het grammaticale geslacht van een dier in het Pools altijd met het natuurlijke geslacht overeenkomt, maar een Poolse spreker wordt door de grammaticale regels gedwongen om een woord, overeenkomstig met zijn grammaticale geslacht, als mannelijk, als vrouwelijk of als neutraal te behandelen" (Kalla 64). De illustraties spelen dus met andere woorden handig in op iets wat grammaticaal gewoon natuurlijker aanvoelt. Bovendien krijgen bepaalde interacties tussen de dieren, zoals bij elkaar op de koffie gaan, een verjaardag vieren of zelfs een emotioneel gesprek, zo een extra lading die in het originele werk niet terug te vinden is, "overeenkomstig het traditionele rollenpatroon dat in de Poolse culturele context sterk aanwezig is" (Kalla 64). Deze poging tot realistischere illustraties brengt "de verhalen van Tellegen jammer genoeg terug tot in hun essentie van dierenverhalen", terwijl zij veel meer zijn dan dat (Boshouwers 67). Boshouwers gaat verder:

Het is gebleken dat overmatige getekende en verzonnen details afbreuk kunnen doen aan de stilte die deze verhalen in zich dragen en de details kunnen de verhalen daardoor reduceren tot niet méér dan komische dierenverhalen. (...) Een al te diepe, realistische weergave zou afbreuk kunnen doen aan het geheel. Het is aan de lezer die ze ter hand neemt om de eventuele dubbele bodem te ontdekken (68).

Brengen we de vier categorieën die de verbinding tussen het tekstuele en visuele aspect van een tekst kunnen beschrijven in herinnering, dan zijn de originele werken wellicht in te delen in het suggestieve, expressieve luik en zijn hun Poolse versies eerder descriptief en decoratief. Men kan dus concluderen dat het herwerkte visuele aspect in de Poolse vertalingen eerder inzet op domestication om zo zijn lezer te helpen bij het verwerken van de inhoud.

\subsection{Eén tekst, twee lezers. Dual address bij Tellegen}

Bovendien wordt door deze visuele aanpassingen op structureel niveau meer ingezet op de read-aloud ability van de tekst. Immers, door Stiasny's handge- 
schreven fragmenten die dynamischer aandoen dan het eerder statische origineel, wordt het voor de voorlezer eenvoudiger nadrukken te leggen of een verschil te maken in intonatie. De opvallendere illustraties kunnen meer interactie veroorzaken tussen voorlezer en luisteraar: een geloofwaardig handschrift brengt doorgaans vertrouwdheid binnen voor een lezer (Oittinen "On translating picture books" 116).

De verhalen van Tellegen lenen zich goed tot een analyse van de dual address, want hoewel zijn werk doorgaans geclassificeerd wordt onder jeugdliteratuur, ontbreken er veel elementen die hier normaliter eigen aan zijn. Literatuurcritica en schrijfster Bregje Boonstra verwoordt het als volgt:

Waar de dierenverhalen over gaan is moeilijk vast te stellen, want in het bos gebeurt voornamelijk niets. Men komt elkaar tegen, zit wat in de zon, denkt een gedachte en voert een min of meer samenhangend gesprek. Het leven vloeit traag als stroop, er hoeft nooit iets, er heerst grote tevredenheid en slechts af en toe roeren zich vage verlangens, wil iemand tijdelijk iets anders of even weg, naar hij weet niet precies waar (24).

Tellegens werk zit dus net vol van abstractie, dubbelzinnigheid en traagheid en ontbeert beweging en zekerheid (vgl. 2.2.1). Toch voldoen de verhalen aan andere geldende conventies over de relatie tussen volwassene en kind binnen de jeugdliteratuur. Zo ontbreekt - net als in sprookjes - een kadering in tijd en ruimte en komen er belangwekkende thema's als angst, tijd, dood, liefde en vriendschap, geluk, en nog veel meer, aan bod. De dual address, de symbiotische relatie tussen volwassene en kind als dubbele bestemmeling, komt dus ook bij de verhalen van Tellegen tot stand.

\section{Conclusie}

In dit artikel werd geanalyseerd hoe de Poolse vertalingen van twee werken van de Nederlandse auteur Toon Tellegen (De verjaardag van alle anderen en Bijna iedereen kon omvallen) functioneren in hun nieuwe doelsysteem. Er is hier een discrepantie tussen aanpassingen op het tekstuele en het visuele niveau. Vertaalster Jadwiga Jędryas leunt nauw aan bij de brontekst en kiest waar mogelijk ervoor om de cultuurvreemde elementen uit het origineel te bewaren. Dit getuigt van het feit dat het kind in de Poolse context wel degelijk gezien wordt als volwaardige, bekwame lezer, en dat ook de volwassene mee in rekening wordt gebracht zoals dat in de originele verhalen gebeurt. De enige ingrijpende adaptatie op het tekstuele niveau is het toevoegen van paratekstuele elementen zoals een korte inleiding en biografie van de auteur.

Op visueel vlak komt illustratrice Ewa Stiasny de Poolse jonge lezer dan weer wel tegemoet. Haar illustraties zijn kinderlijker, haar vormgeving en typologie expressiever. Kortom, het visuele en tekstuele gaan in de Poolse uitgaven 
veel nauwer samen, wat de dierenverhalen dreigt terug te brengen tot fantasieverhaaltjes in plaats van recht te doen aan de filosofische dubbele bodem die zij hebben. Eventuele leemtes in de tekst die de lezer normaal zelf kan invullen, worden hier al beantwoord in de illustraties, die vaak een scène of gebeurtenis expliciet maken, terwijl de originele illustraties niet zo concreet zijn. Dat gegeven antwoord past dan bovendien goed in de Poolse culturele context; waarvan het bevestigen van het traditionele rollenpatroon een goed voorbeeld is. Het visuele aspect kiest met andere woorden voor domestication. Toch zijn er ook voordelen: het maakt de verhalen wellicht toegankelijker voor een jonger publiek en bevordert bovendien de read-aloud ability.

Hoewel beide werken van Tellegen zich goed tot een analyse lenen, kunnen enkel op basis van dit artikel geenszins algemeen geldende conclusies getrokken worden. Het zou dan ook goed zijn om andere werken van Tellegen aan eenzelfde analyse te onderwerpen. Verder spelen er bij het vertalen en herwerken van (jeugd) boeken ook nog vaak andere factoren mee (m.b.t. uitgeverijen, rechten, en andere economische of persoonlijke overwegingen, zie Van Coillie \& McMartin 15) die hier niet mee in rekening zijn gebracht.

\section{Bibliografie}

\section{Primaire literatuur}

Tellegen, Toon. Bijna iedereen kon omvallen. Em. Querido Uitgeverij B.V, 1993.

---. De verjaardag van alle anderen. Em. Querido Uitgeverij B.V, 1998.

---. Nie każdy umiat się przewrócić, vertaald door Jadwiga Jędryas. Wydawnictwo Dwie Siostry, 2013.

---. Urodziny prawie wszystkich, vertaald door Jadwiga Jędryas. Wydawnictwo Dwie Siostry, 2014.

\section{Secundaire literatuur}

Boonstra, Bregje. "Een dier denkt wat af". Literatuur zonder leeftijd, vol. 28, 1993, pp. 23-28.

Boshouwers, Suzan. "Over de zin van zinloze dromen van de eekhoorn: Herinneringen aan inktmet-spatten van juffrouw Kachel en over de diversiteit van de illustraties bij de verhalen van Toon Tellegen". Leesgoed, vol. 2, 2000, pp. 66-69.

Czarnecka, Bożena. "De Nederlandstalige literatuur in de themanummers van Poolse literaire en algemeen-culturele tijdschriften na 1945". Werkwinkel, vol. 2, no. 1, 2007, pp. 13-41.

Dymel-Trzebiatowska, Hanna. "Dual or single address? Some reflections on Hans Christian Andersen's fairy tales in Polish translations". Forum for World Literature Studies, vol. 3, no. 2, 2011, pp. 195-203.

Ghesquière, Rita. Jeugdliteratuur in perspectief. Acco, 2009.

---. "Why Does Children's Literature Need Translations?" Children's literature in translation: Challenges and strategies, geredigeerd door Jan Van Coillie en Walter P. Verschueren. St Jerome, 2006, pp. 19-33. 
Hervey, Sándor G.J. “Ideology and Strategy in Translating Children's Literature”. Forum for Modern Language Studies, vol. 33, no. 1, 1997, pp. 60-71. https://doi.org/10.1093/fmls/XXXIII.1.60.

Kalla, Irena Barbara. "De mier op hoge hakken: Toon Tellegen en Anne Provoost in Polen". Literatuur zonder leeftijd, vol. 81, 2010, pp. 61-77.

Klaver, Marie-José. “Toon Tellegen: Ze wisten er meer van”. (recensie), https://www.tzum. info/2020/12/recensie-toon-tellegen-ze-wisten-er-meer-van/. Geraadpleegd 1 juli 2021.

Klingberg, Göte. Children's fiction in the hands of the translators. CWK Gleerup, 1986.

Lathey, Gillian. "Introduction”. The Translation of Children's Literature: A reader, geredigeerd door Gillian Lathey. Multilingual Matters, 2006, pp. 1-14.

---. "The Translator Revealed: Didacticism, Cultural Mediation and Visions of the Child Reader in Translators' Prefaces". Children's literature in translation: Challenges and strategies, geredigeerd door Walter P. Verschueren en Jan Van Coillie. St Jerome, 2006, pp. 1-18.

López, Marisa Fernández. "Translation Studies in Contemporary Children's Literature: A Comparison of Intercultural Ideological Factors". The Translation of Children's Literature: A reader, geredigeerd door Gillian Lathey. Multilingual Matters, 2006, pp. 41-53.

Michułka, Dorota, en Ryszard Waksmund. "Polish Literature for Children and Youth in a Comparative Perspective (Selective Problems)". Interlitteraria, vol. XIX, no. 1, 2014, pp. 152-156.

Oittinen, Riitta. "No Innocent Act: On the Ethics of Translating for Children". Children's literature in translation: Challenges and strategies, geredigeerd door Jan Van Coillie en Walter P. Verschueren. St Jerome, 2006, pp. 19-33.

---. "On translating picture books". Perspectives, vol. 9, no. 2, 2001, pp. 109-125. https://doi.org/10. 1080/0907676X.2001.9961410.

O'Sullivan, Emer. “Translating pictures”. The Translation of Children's Literature: A reader, geredigeerd door Gillian Lathey. Multilingual Matters, 2006, pp. 113-121.

Pounds, Gabrina. “'Foreignizing' or 'Domesticating' the Ideology of Parental Control in Translating Stories for Children: Insights from Contrastive Discourse Analysis". Applied Linguistics, vol. 32, no. 3, 2011, pp. 277-298. https://doi.org/10.1093/applin/amq052.

Puurtinen, Tiina. "Translating Children's Literature: Theoretical Approaches and Empirical Studies". The Translation of Children's Literature: A reader, geredigeerd door Gillian Lathey. Multilingual Matters, 2006, pp. 54-64.

Rudvin, Mette, en Francesca Orlati. "Dual Readership and Hidden Subtexts in Children's Literature: The Case of Salman Rushdie's 'Haroun and the Sea of Stories"'. Children's literature in translation: Challenges and strategies, geredigeerd door Jan Van Coillie en Walter P. Verschueren. St Jerome, 2006, pp. 157-184.

Schwarcz, Joseph H. Ways of the illustrator: Visual communication in children's literature. American Library Association, 1982.

Shavit, Zohar. "Translation of Children's Literature". The Translation of Children's Literature: A Reader, geredigeerd door Gillian Lathey. Multilingual Matters, 2006, pp. 25-40.

Shulevitz, Uri. Writing with Pictures. How to Write and Illustrate Children's Books. Watson-Guptill, 1985.

Staal, Jos. "Toon Tellegen". Lexicon van de jeugdliteratuur, vol. 84, 2010, pp. 1-13.

Szymańska, Izabela. "Wymiary obcości w przekładzie dla dzieci”. Między Oryginałem a Przekładem, vol. 15, 2009, pp. 155-172.

Van Coillie, Jan. "'Oh, how hard it is to play the translator's game': Translating Orality in the Grimms' 'Rumpelstiltskin'”. Marvels \& Tales; Detroit, vol. 28, no. 2, 2014, pp. 346-365, 437.

Van Coillie, Jan, en Jack McMartin. Children's Literature in Translation: Texts and Contexts. Leuven University Press, 2020.

Vrooland-Löb, Truusje. "Eenheid of verscheidenheid? De tekenaars van Toon Tellegen". Literatuur zonder leeftijd, vol. 30, 1994, pp. 59-68.

Wall, Barbara. The Narrator's Voice: The Dilemma of Children's Fiction. Macmillan, 1991. 